\title{
Introduction of HER-2 and a Short Review on Its Role in Prognosis and Treatment of Breast Cancer
}

SeyedAbbas Mirmalek ${ }^{1}$, Fatemeh Elhamkani², Seyed Alireza Salimi Tabatabaee ${ }^{3}$, Hossein Mahmoodzadeh ${ }^{2}$, Yekta Parsa $^{3}$, Soheila Yadollah-Damavandi ${ }^{3}$, Ehsan Jangholi ${ }^{4}$

${ }^{1}$ Department of Surgery, Islamic Azad University, Tehran Medical Sciences Branch, Tehran, Iran ${ }^{2}$ Tehran University of Medical Sciences and Health Services, Shariati Hospital, Tehran, Iran

${ }^{3}$ Students' Research Committee, Islamic Azad University, Tehran Medical Sciences Branch, Tehran, Iran

${ }^{4}$ Young Researchers Club, Islamic Azad University, Tehran Medical Sciences Branch, Tehran, Iran

\begin{abstract}
Human Epidermal growth factor Receptor-2 (HER-2) as a new prognostic and predictive factor has been believed as an essential measurement in breast carcinoma. About 280 articles were reviewed and 115 were referred in this review article on HER-2. HER-2 is an oncoprotein epidermal growth factor receptor produced by a so-called cell surface oncogene. Overexpression results in aggressive behavior, early metastasis to lymph nodes and distant areas, and poor prognosis in breast cancer. HER-2 seems to be a prognostic and predictive factor and must be considered in all breast cancer cases.[GMJ.2014;3(3):132-44]
\end{abstract}

Keywords: Breast Cancer; Human Epidermal growth factor Receptor-2; Prognosis; HER-2; Review

\section{Introduction}

Deptide growth factors regulate cell division and differentiation. They have a significant role in initiation and persistence of neoplastic changes. Growth factors and their receptors are the products of several activated proto-oncogenes. Among them, a well-studied group is Type I Receptor Tyrosine Kinase (RTKs). This family includes 4 homologous receptors: HER-1, HER-2, HER-3, and HER4 , which are the products of c-erbB ${ }_{1}, \mathrm{c}-\mathrm{erbB}_{2}$, c-erbB ${ }_{3}$, and c-erbB $\mathrm{B}_{4}$ proto-oncogenes, respectively. HER-2 is the best known and the most important receptor due to its exclusive properties [1-3]. Proto-oncogenes are converted

\section{GMJ}

2013 Galen Medical Journal

Fax: +98 7312227091

PO Box 7461686688

Email:info@gmj.ir to oncogenes via different processes such as mutation or amplification, which activate or overexpress their products [4].

HER-2 or c-erbB ${ }_{2}$ is a natural human proto-oncogene located on the long arm of chromosome 17 (17q21) and can be amplified by unknown factors and converted to HER-2 oncogene, resulting in overexpression of a homonymous $185 \mathrm{kDa}$ protein in cell membrane. As a member of epidermal growth factor receptor family, HER-2 is a transmembrane epidermal growth factor receptor possessing an extracellular and an intracellular component. This protein is found in various tissues including breast, ovary, lung, digestive tract,

\footnotetext{
Correspondence to:

Seyed Abbas Mirmalek ,Department of Surgery, Islamic Azad University, Tehran Medical Sciences Branch, Tehran, Iran

Telephone Number: (+98) 2188787561

Email Address :sam@mirmalek.net
} 
kidneys, and central nervous system $[5,6]$. HER-2 gene is amplified in about one-third of invasive breast cancers, resulting in production of numerous copies (50-100) of the gene in each cell, rather than two copies (one in each chromosome). This leads to overexpression of HER-2 protein, so that up to 2,000,000 HER-2 molecules may exist in neoplastic cells, instead of 20,000-50,000 copies per cell in normal tissues. This change is a non-hereditary event, still with unknown causes.

The extracellular component of HER-2 receptor binds to special ligands called hergulins/ neuregulins, which enhance its kinase activity and hence tyrosine phosphorylation. This process induces signaling pathways inside cells and causes their overgrowth and uncontrollable division [8-10]. HER-2 gene amplification is observed in $25-30 \%$ of invasive ductal carcinoma [11-14], about $60-75 \%$ of ductal carcinomas in situ (DCIS), $100 \%$ of DCIS Comedo type, and a small percentage (about $0.8 \%$ ) of invasive lobular type [15-18]. However, different statistics on the frequency of HER-2 positives have been reported from different regions of the world: $58.5 \%$ in Iran [19], 57.8$67 \%$ in China [20-21], 55\% in Sweden [22], $53 \%$ in Taiwan[23], 46\% in Greece [24], 44\% in Germany [25], 26\% in Qatar [26], 19\% in Austalia [27], 18.1\% in England [28], 18\% in Spain [29], and 10-15\% in Japan [30].

Salmon et al. (1987) were the first to show that HER-2 gene amplification can independently predict the overall survival (OS) and the disease free survival (DFS) in breast cancer suffering patients with lymph node involvement [31-36]. HER-2 is an independent predictor of the disease prognosis in patients without lymph nodes involvement as well. A study in Canada on 580 breast cancer patients without lymph node involvement showed that the relapse risk was higher in HER-2 $2^{+}$patients [37]. HER-2 measurement methods

Given the ever-increasing importance of HER-2, its measurement is recommended routinely in all recently diagnosed breast cancer patients, although it may be measured in archival samples (blocks) of breast cancer [38]. In addition, recent researches have reported the ability to measure HER-2 by core needle biopsy [39]. Various methods are used to assess HER-2 status [40, 41].

1. HER-2 assessment methods at gene level performed through Polymerase Chain Reaction (PCR), Fluorescence in situ Hybridization (FISH), and Southern Blot.

2. HER-2 assessment methods at transcription level performed through reverse time (RT)-PCR and Northern Analysis.

3. HER-2 assessment methods at transcription level performed through Enzyme-Linked Immunosorbent Assay (ELISA), Immunohistochemistry (IHC), and Western Blot.

HER-2 assessment with PCR and Southern Blot is abundantly performed in research, rather than clinics [42], while FISH is a quantitative and precise, or better said the most accurate method to study HER-2 gene amplification. A fluorescent-labeled DNA probe including HER-2 is used in this method. The DNA probe is approached to the DNA of tumor cells fixed in paraffin on a slide and attaches it. Then a second DNA probe whose chromosome 17 was labeled with another stain is used. This second probe attaches also to HER-2 and the product is used as control. Finally, the rate of florescent HER-2 attachment to tumor cells is compared with the rate of the second probe (healthy control) attachment to florescent HER-2. This approach gives rise to a copy with certain number of HER-2 gene in chromosome 17. Despite being quantitative and accurate, this method is costly and it is difficult to access to laboratories able to perform it [33, 41, 44].

However, IHC is a common and easily accessible method for assessment of HER-2 status [44-46].

Through this method, HER-2 protein is measured at cell level. A slide of tumor tissue is stained with an anti-HER-2 antibody and then the tumors are classified according to the rate of stainability into HER-2-, HER-2 ${ }^{+}$, HER$2^{++}$, and HER-2 $2^{+++}$.

The disadvantages of this method are as follows:

1. IHC is performed as quantitative and subjective, rather than objective. Therefore, it is not as accurate as FISH. Some studies compared HER-2 measurement accuracy of FISH and IHC and showed that in some 
instances HER-2 $2^{+}$and HER-2 $2^{++}$in IHC are not determined as positive in FISH and only HER-2 $2^{+++}$is considered certainly HER-2 positive. However the method is used throughout the world like Iran due to its cheapness, rapidity, and ease of access $[19,47]$.

2. Another disadvantage of IHC is the use of different types of antibodies, each with different sensitivity and specificity; this may result differently for HER-2 assessment in two different laboratories.

3. Maintenance of samples in formalin or their fixing in paraffin can alter cells, leading to reduction of the sensitivity of HER-2 measurement through IHC.

Given the mentioned disadvantages of IHC, FISH is currently introduced as the standard method for measurement of HER-2 [41,42].

\section{Serum levels of HER-2}

Several reports suggested the assessment of HER-2 in serum, saliva, or breast secretions. HER-2 is measured through ELISA [48,49], in these liquids merely for research rather than clinical use. However, studies have shown that HER-2 measurement in patients' serum can help detect it prior to metastasis. A study showed that increased serum levels of HER-2 in $50 \%$ of patients revealed occult metastases 3 to 6 months before emergence of clinical symptoms [50]. This is a new advancement in timely prevention and treatment of metastasis. As a marker, HER-2 can be measured in serum of treated breast cancer patients for their next follow-up [51]. A study in USA on the saliva of patients with breast cancer suggested the use of this method for screening of breast cancer [52].

HER-2 serum levels increase with the disease severity. Increased serum levels of HER-2 ( $>$ $15 \mathrm{mg} / \mathrm{ml}$ ) can be found in $1.7 \%$ of patients in stage $1,3 \%$ of patients in stage $2,16.7 \%$ of patients in stage 3 , and $35.5 \%$ of patients in stage 4 [51].

HER-2 serum level is also correlated to the disease progression and relapse. In addition, increased serum levels of HER-2 may predict lower responsiveness to hormone therapy in $\mathrm{ER}+$ patients. In early studies, salivary levels of HER-2 in women with breast cancer were definitely and markedly higher than healthy women or those with benign tumors of breast $[53,54]$. A study in Iran (2004) showed that the prevalence of HER-2 $2^{+}$in malignant tumors was significantly higher than normal breast tissue surrounding the tumor [47]. Research has shown that HER-2 serum levels in patients under adjuvant therapy (chemotherapy and radiotherapy) were decreased significantly proposing the impact of the treatments. Therefore, HER-2 levels can be used to assess the effectiveness of treatment [55].

\section{HER-2 and Ductal Carcinoma In Situ (DCIS)}

As mentioned earlier, positive results of HER2 in DCIS are higher in invasive breast cancer (60-75\% versus 25-30\%). Numerous genetic events are required to convert an in situ malignancy to an invasive type. Some studies suggest that HER-2 gene amplification and hence HER-2 protein overexpression may be the most important factors of in situ cancer progression toward invasive malignancy [56], although further research is needed to confirm this theory. The strong correlation of HER2 with DCIS proposes that HER- 2 may be a possible marker of relapse after conservative treatment of DCIS [15-18].

\section{HER-2 and Estrogen Receptor (ER) Status}

ER is a prognostic and predicting factor of breast cancer. ER+ patients have a better prognosis than ER- ones and better respond to anti-estrogen drugs (e.g., Tamoxifen), which have become an important principle in the treatment of breast cancer [57, 58].

Numerous studies revealed that HER-2+ and $\mathrm{ER}+$ tumors show lower response to hormone therapy than HER-2- and ER+ tumors; this seems to be due to intracellular functional interference of HER-2- with hormone receptors which result in resistance of some ER+ tumors to tamoxifen [59].

In a study in United States (2003), introduction of HER-2 into MCF-7 cell line of breast cancer, which is dependant and sensitive to anti-estrogen drugs, resulted in cells that were independent on estrogen and resis- 
tant to anti-estrogen drugs (e.g., tamoxifen). When the yielded cells were inoculated by anti-HER-2 antibody, estrogen receptors were reconstructed and the cells gained their sensitivity to anti-estrogen drugs. These studies suggest that there is a definite and specific correlation between estrogen receptors and HER-2 and that the sensitivity can be reestablished with anti-HER-2 antibody (Herceptin). Hence, administration of this medicine along with anti-estrogen drugs can be considered a treatment principle in breast cancer patients during pre-menopausal ages $[60,61]$. A significant and specific correlation seems to exist between ER- and HER-2+ as well, both of which are indicators of poor prognosis for breast cancer patients [62-65]. Even in patients with HER-2+ and ER+ tumors, ER quantification revealed that its level in HER$2+$ tumors was lower than those of HER-2-, and this issue may demonstrate a process of partial resistance to hormone therapy in HER$2+$ patients $[60,66]$.

\section{HER-2 and P53}

TP53 is a tumor suppressor locating on chromosome 17 and its role as a down-regulator of cell division is well-known in various tumors including breast cancer. TP53 is the best-known mutated gene in human cancers. Facing with stimuli such as ionizing radiation, chemotherapy, acidosis, deprivation from growth factors, and hypoxia, normal p53 which is the product of TP53 gene halts cell cycle through mediating certain pathways and leads cells toward apoptosis. Mutated TP53 produces a half-life-increased protein lacking native conformation and unable to perform its normal activities. Overexpression of p53, occurred in approximately $30 \%$ of breast cancers, can be well assessed through IHC; it is also correlated to high nuclear differentiation, aneuploidy, increased cell cycle, HER-2+, and ER-. Several studies showed that positive p53 in breast cancer predicts a weaker prognosis in these patients $[67,68]$. It was also shown in some studies that overexpression of p53 and HER-2, as two independent factors, can estimate the survival in breast cancer patients, regardless of metstasis $[50,69]$.
A research was launched in Alabama University to determine the prognosis of breast cancer using biomarkers. It was revealed after 15 years of follow-up that a combination of HER-2 and p53 overproduction can predict disease free survival (DFS) and overall survival (OS) with greater accuracy than other clinical-pathological factors [70]. A study in Japan (2003) showed that concurrent incidence of p53 and HER-2 has a more specific and more definite prognostic value than when one of them is positive and that the prognostic value of these factors are independent of the others.[71]

\section{HER-2 and Pathologic Type of Tumor}

Overexpression of HER-2 is seen in all well differentiated DCISs (Comedo type), 60-75\% of all DCISs, $25-30 \%$ of ductal invasive carcinomas, and in a small percentage of lobular invasive carcinomas.

The pathologic type of tumor is also a prognostic factor in breast cancer. That is to say, the best prognosis is seen in tubular and the worse in ductal carcinoma of not specified type (NST) [72, 73].

A study was performed in Australia to assess the status of HER-2 in breast cancer based on clinical, histological, and pathological information. It showed that $95.5 \%$ of HER-2+ tumors were ductal carcinoma and only $0.8 \%$ was lobular. The researchers suggested that due to a weak possibility of positivity of HER2 in lobular carcinoma, routine assessment of HER-2 is not necessary, while the highest positive HER-2 was seen in ductal carcinoma of NST [13]. Therefore, there is a specific and significant relationship between HER-2+ and ductal invasive carcinoma of breast [74].

\section{HER-2 and the Grade of Differentiation}

Differentiation grading is the strongest and best-known prognostic factor in breast cancer [54]. Tissue differentiation is considered as the morphologic marker of tumor invasiveness. This factor acts somewhat independent of lymph nodes and is routinely determined in tumor specimens.

There are various methods for determining 
differentiation, and Bloom and Richardson grading system is the best-known and the most used. The grading is performed based on three properties including tubules formation, mitosis counts, and nuclear polymorphism. Tumors are included in the following groups according to the obtained scores [67].

\begin{tabular}{lcl}
\hline $\begin{array}{l}\text { Well } \\
\text { Differentiated }\end{array}$ & Score 3-5 & $\begin{array}{l}\text { Grade I: } \\
\text { Low grade }\end{array}$ \\
\hline $\begin{array}{l}\text { Moderately } \\
\text { Differentiated }\end{array}$ & Score 6-7 & $\begin{array}{l}\text { Grade II: } \\
\text { Intermediate } \\
\text { grade }\end{array}$ \\
\hline $\begin{array}{l}\text { Poorly } \\
\text { Differentiated }\end{array}$ & Score 8-9 & $\begin{array}{l}\text { Grade III: } \\
\text { High grade }\end{array}$ \\
\hline
\end{tabular}

Poorly differentiated tumors are in minority. It seems that tissue differentiation grade increases with tumor enlargement and disease progress. As an individual property, tissue differentiation grade is a definite and specific predictor of mortality in breast cancer. When the nuclear and tissue differentiation grade is low, the tumor will better respond to chemotherapy. That is to say, adjuvant chemotherapy in a patient with lymph node involvement and a grade III tumor will have better prognosis than a patient with node+ and a grade I tumor [77].

Prognostic effects of differentiation grading are also obvious in patients without lymph node involvement. In a study by Fisher, it was shown that in comparison with hormone receptors, grading was an important determining factor of patients' outcome. In terms of DFS estimation, grading ranks the second after tumor size, therefore one can predict that the 5-year survival in a patient with well differentiated breast cancer and without lymph node involvement will be near 100\% [78].

In general, the 5-year survival in patients with well-differentiated, moderately differentiated, and poorly differentiated tumors is $95 \%, 75 \%$, and $50 \%$, respectively. The multivariate analyses also highlights the differentiation grading as the strongest predictor of breast cancer-induced death [51].

In a study in United States (2003), the association of HER-2 ${ }^{+}$and G III was significant $(\mathrm{P}=0.0004)$ [18].

Moreover, a study was performed in Spain
(2003) which proved that $97 \%$ of HER-2+ patients were in differentiation grades of II or III [13] while in a similar study in Spain in the same year, the majority of HER-2+ patients were well differentiated [29].

\section{HER-2 and Age}

A study in Iran (2003) on 2000 patients suffering from breast cancer showed that the number of patients with HER-2+ in peri-menopausal years (46-55) was higher than older patients. Therefore, the majority of cancer in this age range included HER-2 ${ }^{+}, \mathrm{ER}-, \mathrm{p} 53^{+}$, indicating poorer prognosis of them in comparison with older patients [19]. This outcome was also obtained in USA in 2003, revealing that the mean age of HER-2 $2^{+}$patients was lower than HER $-2^{-}$ones, i.e. HER-2 $2^{+}$is frequently seen in younger ages. This can be attributed to the fundamental pathologic differences in breast cancer of younger patients and may indicate higher risk of relapse [18].

A similar study was carried out in Switzerland (2002) to evaluate breast cancer biomarkers and their correlation with the age of sufferers. It was concluded that breast cancers emerging at higher ages grow slowly and have higher possibility of $\mathrm{ER}^{+}$and lower possibility of HER-2 ${ }^{+}$and positive p53 [79].

\section{HER-2 as a Prognostic Factor for Breast Cancer}

HER-2 overexpression results an increase in cell signaling relevant to mitosis and cell division. This molecular alteration leads to a poor prognosis in the early phases of breast cancer and shortening of disease course and relapse interval, as well as overall survival of patient [80]. Overexpression of HER-2 is an independent prognostic factor in breast cancer and increases 2-3 times the risk of relapse in patients either with or without lymph node involvement [81-83].

In HER-2 ${ }^{+}$patients, metastasis occurs faster than those with HER-2- ${ }^{-}$, so that HER-2 is considered an independent prognostic factor of survival without metastasis [50].

Various studies showed that HER-2 is an undesirable prognostic factor in breast cancer 
patients $[84,85]$. Given the abundant information obtained about HER-2, it is suggested to routinely measure HER-2 in all breast patients $[31,86]$.

In a study in Japan on 239 patients with breast cancer, HER-2- patients had significantly longer survival after their first relapse. In this research, HER-2 was proposed as an independent prognostic factor after relapse [32]. A multivariate analysis in Spain (2002) revealed that high levels of HER-2 in serum of breast cancer patients with lymph node involvement doubles the risk of relapse and the resulted mortality, when compared with those having normal HER-2 levels. Given the relation of high HER-2 titers to DFS and OS, this research suggested to quantify HER-2 with ELISA in order to identify the breast cancer patients at higher risk of relapse and to treat them more invasively [33].

In a multivariate analysis performed in Germany (2004), HER-2 was assessed and compared with CA15-3. The study revealed that HER-2 is a strong, independent prognostic factor of survival after relapse in patients with metastatic breast cancer. In contrast, CA15-3, which is per se a tumor load marker, had no significant correlation with survival after relapse. Therefore, it seems that the prognostic effect of HER-2 may be associated not only with tumor load but also with its biologic behavior [35].

Another study in Finland in 2004 investigated the early phases of breast tumors $\left(\mathrm{T}_{1} \mathrm{~N}_{0} \mathrm{M}_{0}\right)$ and their relationship with HER-2. The study stated that despite expecting a very good outcome of patients in early phases of breast cancer, sometimes unexpected mortalities are seen in these patients. Accordingly, numerous biomarkers were studied in these patients concluding that overexpression of HER-2 can be a reliable factor in determining unfavorable prognosis of this phase in patients. However, other markers such as Ki-67+, ER-, and p53+ were also effective [87]. A research was conducted in Italy (2004) on the role of HER-2 in breast metastatic cancer under adjuvant therapy. It was shown that DFS in HER-2+ and HER-2- breast metastatic patients was 17.6 and 44 months, respectively, while OS was 27.6 and 50.3 months in HER-2 ${ }^{+}$and HER-2 breast metastatic patients, respectively. These results showed that overexpression of HER-2 leads to a bad outcome for breast metastatic patients under chemotherapy. This is in spite of the fact that these patients respond better to chemotherapy regimens than HER-2- patients [88]. In a study in Australia in 2004, HER-2 was introduced as a completely independent prognostic factor for breast cancer. Therefore, the researchers may find any correlation between HER-2 and other prognostic factors such as differentiation grade, tumor size, ER status, and lymph node involvement [27].

Since lymph node status is a distinguishing factor in the prognosis of breast cancer, there seems to be some contradictions in prediction of outcome in patients without lymph node involvement. In this regard, a study on 580 breast cancer patients without lymph node involvement in Canada concluded that an increased risk of relapse exists in HER-2+ patients without lymph node involvement. Therefore, results of this study emphasized on the obvious role of HER-2 in determining the prognosis in patients without lymph node involvement [37].

A study in Greece (2004) showed that the prognostic strength of pathology and disease stage is stronger than HER-2 and p53. The researchers suggested performing further studies on the roles of HER-2 and p53. In addition, since HER-2+ patients without lymph node involvement were at higher mortality risk, an adjuvant systematic invasive treatment was suggested in such patients [24].

An interesting feature of HER-2 was revealed in a study in Italy (2003) which evaluated the impact of surgery on amplification of HER-2 ${ }^{+}$ breast cancer. The results showed that when the remaining breast cancer, which was operated 48 days after the initial surgery was HER- $2^{+}$, these tumors showed higher amplification than those of HER-2- In this study, wound drainage and serum specimens were exposed to HER-2 $2^{+}$cancerous cells in vitro which resulted in their increased growth. However, when HER-2 was removed from membrane, a definite and specific decline in amplification occurred. The issue was justified by the researchers so that the existence of growth factors like epidermal growth factor in 
serum samples and wound drainage after surgery stimulate HER-2 as a receptor of epidermal growth factor and result in amplification and growth of cancer cells after surgery [89]. HER-2 as a determining factor for breast cancer treatment policy

The most appropriate systematic treatment for a population of breast cancer patients is determined through clinical trials. Variety of breast cancer results in different advantages of a therapeutic regimen for every patient. Therefore, in order to prescribe treatment for each patient proportional to her cancer characteristics, physicians require factors estimating response to treatment [90]. One of the most important and well-known factors is the status of estrogen receptor which positivity necessitates an anti-estrogen (tamoxifen) treatment [91].

HER-2 status is a factor that has been used extensively in recent years. In addition, since overexpression of HER-2 and its increased kinase activity results in invasive behavior of HER-2+ tumors, this factor has become an attractive target for interventional treatments with antibodies that can cope with the kinase effects of HER-2 [92]. In 1998, the human monoclonal antibody of HER-2, called Trastuzumab or Herceptin was approved by FDA. This antibody, which acts against HER-2, has been initially proposed as the standard treatment of metastatic breast cancer [93], while it has gradually become a component of HER$2^{+}$breast cancer standard therapy, alone or in conjunction with other chemotherapeutic agents [94-101]. Studies showed that the best therapeutic response to this drug was seen in IHC-detected HER-2+++ or FISH-positive tumors and that Trastuzumab along with chemotherapy is more effective than chemotherapy alone $[102,103]$. Determining the status of HER-2 not only affects the initiation of anti-HER-2 antibody treatment, but also has a critical role in determining the type of chemotherapy in HER-2+ patients. A study in Italy in 2003 showed that the relapse-free survival and overall survival of HER-2+ breast cancer patients treated with CMF (i.e., Cyclophosphamide, Methotrexate, Fluouracil) and ADM (Adriamycin) were longer than those treated with CMF alone. This study stated that add- ing ADM to CFM in regimens of HER-2+ breast cancer patients contributes to longevity of these patients [104]. Some references mentioned partial resistance to CMF regimen and sensitivity to Doxorubicin in HER-2+ patients [105]. In this regard, some studies were performed on treatment with Trastuzumab prior to surgery. In two similar studies, HER-2+ breast cancer patients in phases 2 or 3 were treated with Trastuzumab and Paclitaxel before surgery and continued with Doxorubicin and Cyclophosphamide after surgery. The results showed a clinical response of $75 \%$. In addition, serum levels of HER-2 were declined after the aforementioned treatment and prior to surgery $[106,107]$.

A study on the effect of weekly and long-term treatment with Trastuzumab and Paclitaxel in HER-2+ breast metastatic cancer showed that not only this regimen was well tolerated by patients but also it affects significantly their outcome. Hence, the survival of advanced and metastatic breast cancer patients increased at least for 6 months $[108,109]$.

Since the status of HER-2 in breast cancer metastases reflects the status of this receptor in early tumors, HER-2 status can be determined in metastatic specimens when early tumor is inaccessible, to possibly use the novel anti-HER-2 treatment in these patients [110$112]$.

\section{Diagnostic and therapeutic applications of anti-HER-2 antibody}

Anti-HER-2 antibody has been recently used for diagnostic purposes. In a study, anti-HER-2 antibody was labeled $\mathrm{Tc}^{99}$, the drug was then administered, and the patients were subjected to scintigraphy. This method can detect the occult cancers with increased HER2 levels [52]. Anti-HER-2 antibody was also used as a radio. It was found that radiotherapy in advanced breast cancer patients will have a better impact if it is associated with Trastuzumab, compared with radiotherapy alone [113].

Anti-HER-2 antibody has been approved by FDA and today it is the standard therapy in HER-2+ breast metastatic cancer. However, despite its advantages it has some side effects. 
Advantages and side effects of treatment with anti-HER-2 antibody

The advantages of anti-HER-2 antibodies can be mentioned as follows:

1. HER-2 is expressed at higher levels in tumor cells.

2. The extracellular portion of the receptor includes two immunoglobulin-like regions, which can be well detected by the antibody. Hence, it can bind strongly to HER-2 receptor, free of cross-reaction with other receptors.

3. Overexpression of HER-2 protein is uniform in cells throughout the malignancy and thus entire cells of a tumor are homogenously exposed to the antibody [114].

Despite its low manifestation, HER-2 is widely distributed in normal tissues and hence prescription of the antibody may block normal HER-2 receptors leading to side effects. However, no drug toxicity has been reported so far, except for a few cases of sensitivity during injection.

Trastuzumab weakens DNA in cancerous cells and strengthens cytotoxic activity of chemotherapeutic agents. Therefore, nowadays it is used as the first line medicine in breast cancer treatment and as the second and third line medicine along with chemotherapeutic agents in breast metastatic cancer. The reason is that numerous studies have reported a proper response to the drug in patients relapsed after chemotherapy. Trastuzumab is more effective when administered along with other chemotherapeutic agents in comparison with the drug alone. However, the rare complications of Trastuzumab, i.e. increase in cardiac dysfunction which is exacerbated when administered along with antracyclins, should be kept in mind [115].

\section{Conclusion}

HER-2 is a prognostic and determining factor for response to treatment in breast cancer and has been abundantly considered recently. Overexpression of HER-2 indicates weaker prognosis, shorter survival, and sooner metastasis. The correlation of HER-2 with other undesirable prognostic factors such as high cellular differentiation, ER-, p53+, and Ki67 , as well as pathologic type of ductal carcinoma (versus lobular carcinoma) significantly helps estimating the obscure outcome of patients. This can be used to identify the high risk groups of patients with more confidence and to consider more invasive treatments, and finally to protect others in low risk groups against side effects and drug-induced toxicities. Discovery of anti-HER-2 antibody has revolutionized the treatment of breast cancer, because this biologic therapy does not have the complications of cytotoxic agents and rather it was approved by FDA as the standard treatment of breast cancer. This study focuses on the importance of HER-2 in breast cancer. Hence, it is suggested to determine routinely this crucial marker in all patients with breast cancer.

\section{Acknowledgments}

Authors wanted to appreciate the scientific writing and editing of the manuscript by scientific writing group managed by Ms. Hasti Nuraei and Dr Soheil Ashkani Esfahani, Shiraz University of Medical Sciences, Shiraz, Iran.

\section{Conflicts of Interest}

None declared

\section{References}

1. Vander Geer P, Hunter T, Lindberg RA.

Receptor protein-tyrosin kinase and transduction pathway. Annu Rev Cell Biol. 1994;10:251-337.

2. Pinkas-Kramaski R, Alory I, Yarden Y. Erb $\mathrm{B}$ receptor and EGF-like ligands: cell lineage determination and oncogenesis through Combinatorial Signaling. J Mamm Gland Biol Neoplasia. 1997;2(2):97-107.

3. Eccles SA. The Role of c - erbB2/Her$2 /$ neu in breast cancer progression and metastasis. J Mammary Gland Biol 
Neoplasia. 2001;6(4):393-406.

4. Blume-Jensen P, Hunter T. oncogenetic kinase signaling. Nature. 2001;411(6835):355-65.

5. Coussens L, Yang-Feng TL, Liao YC, Chen E, Gray A, McGrath J, et al. Tyrosine kinase receptor with extensive homology to EGF receptor shares chromosomal location with neu oncogene. Science. 1985;230(4730):1132-9.

6.

7. King CR, Kraus MH, Auroson SA. Amplification of a novel c - erb - B2 related gene in human mammary carcinoma. Science. 1995;229:974-6.

8. Reese DM, Salmon DJ. HER-2/neu signal transduction in human breast and ovarian cancer. Stem cells. 1997;15(1):1-8.

9. Carraway K, Cantley L. A new acquaintance for erbB3 and erbB4: a role for receptor heterodimerization in growth signaling. Cell. 1996;78(1):5-8.

10. Sliwkowski MX, Schaefer G, Akita RW, Lofgren JA, Fitzpatrick VD, Nuijens $\mathrm{A}$, et al. Coexpression of erbB2 and erbB3 protein reconstitutes a high affinity receptor for heregulin. J Biol chem. 1998; 269(20):14661-5.

11. Plowman GD, Culouscou JM, Whitney GS, Green JM, Carlton GW, Foy L, et al. Ligand - Specific activatinn of HER4/P185 erbB4, a fourth member of epidermal growth factor receptor family. Proc NatI Acad Sci USA. 1993;90(5):1746-50.

12. Burstein HJ, Lieberman G, Slamon DJ, Winer EP, Klein P. Isolated central nervous system metastases in patients with HER2overexpressing advanced breast cancer treated with first-line trastuzumab-based therapy. Ann Oncol. 2005;16(11):1772-7.

13. Zhou BP, Hung MC. Dysregulation of cellular signaling by HER-2/neu in breast cancer. Semi oncol. 2003;30(16):38-48.

14. Bilous M, Ades C, Armes J, Bishop J, Brown $\mathrm{R}$, Cooke B, et al. Predicting the HER2 status of breast cancer from basic histopathology data. Breast. 2003;12(2):92-8.

15. Henahan S. HER-2/neu vs Breast cancer. National health musemn. 2002;1(1).

16. Latta EK, Tjan S, Parkes RK, O’Malley FP. The Role of HER2/neu over expression I amplification in the progression of ductal carcinoma in situ to invasive carcinoma of the breast cancer. Mod Pathol. 2002; 15(12):1318-25.

17. DiGiovanna MP, Chu P, Davison TL, Howe
CL, Carter D, Claus EB, et al. Active signaling by HER2/neu in a Subpopulation of HER-2 over expressing ductal Carcinoma insitu clinicopathological Correlates. Cancer Res. 2002; 62(22):6667-73.

18. Gullick WJ. A new model for ductal carcinoma insitu suggests strategies for treatment. Breast Cancer Res. 2002;4(5):1768.

19. Rodrigues NA, Dillon D, Carter D, Parisot N, Haffty BG. Differences in the pathologic and molecular features of in tra ductal breast carcinoma between younger and older women. Cancer. 2003;97(6):1393-403.

20. Mirmalek S, sadat Yarandi N, Shadpour MT, Saatian M, Raeesi H, Rangraz EJ, et al. Evaluation of Morphological Changes in Breast Cancer: Influence of Fractal Meta-Analysis. Galen Medical Journal. 2014;3(2):130-1.

21. Yang JQ, Chen L, Xing TY. Relationship of oncogene C-erbB2 expression to ER, PR and PS2 in breast cancer and its prognostic significance. Sichuan Da Xue Xue Bao Yi Xue Ban. 2004;35(3):334-6,357.

22. Mai GF, Zheng H, Luo RC, Liao WJ, Zhang LS, He XB. Association of progesterone receptor and HER-2 expressions with the survival time of patient with breast cancer. Di Yi Jun 2003 Apr; 23(4): 372-4.

23. Gancberg D, Di Leo A, Cardoso F, Rouas G, Pedrocchi M, Paesmans M, et al. Comparison of HER-2 status between primary breast cancer and corresponding distant metastatic site. Ann Oncol. 2002;13(7):1036-43.

24. Chen HH, Su WC, Guo HR, Chang TW, Lee WY. P53 and C-erbB2 but not bcl-2 are predictive of metastatic-free survival in breast cancer patients receiving past mastectomy adjuvant raidio therapy in Taiwan. Jpn J Clin Oncol. 2002;32(9):332-9.

25. Korkolis DP, Tsoli E, Fouskakis D, Yiotis J, Koullias GJ, Giannopoulos D, et al. Tumor histology and stage but not p53, HER2 / neu or cathepsin D expression and independent prognostic factors in breast cancer patients. Anticancer Res. 2004;24(310):2061- 8.

26. Zemzoum I, Kates RE, Ross JS, Dettmar $\mathrm{P}$, Dutta M, Henrichs C, et al. Invasion factor UPA/PAI-1 and HER-2 status provide independent and complementary information on patient outcome in node - negative breast cancer. J Clin Oncol. 2003;21(6):1022-8.

27. Rasul KI, Mohammaed K, Abdalla AS, Chong-Lopez A, Ahmad MA, Al-Homsi MU, 
et al. study of HER-2/neu status in Gatari women with breast Carcinoma. Saudi Med J. 2003;24(8):832-6.

28. Dandachi N, Dietze O, Hauser-Kronberger C. Evaluation of the clinical significance of Her-2 amplification by chromogenic in situ bybridisation in patients with primary breast cancer. Anti Cancer Res. 2004;24(4):2401-6.

29. Carney WP, Neumann R, Lipton A, Leitzel K, Ali S, Price CP.. Monitoring the circulating levels of the HER-2/neu Onco protein in Breast Cancer. Clin Breast Cancer. 2004;5(2):105-16.

30. López-Guerrero JA, Navarro S, Noguera $\mathrm{R}$, Almenar S, Pellin A, Vázquez C, et al. Histological tumor grade Correlate with Her2 status in invasive breast cancer. Arkh patol. 2003;65(1):50-5.

31. Kumar-Sinha C, Ignatoski KW, Lippman ME, Ethier SP, Chinnaiyan AM.

Transcription analysis ofHER-2 reveals a molecular connection to fatty Acid synthesis. Cancer Res. 2003;63(1):132-9.

32. Hayes DF, Walker TM, Singh B, Vitetta ES, Uhr JW, Gross S, et al. Monitoring expression of HER-2 on circulating epithelial cells in patients with advanced breast cancer. Int J Oncol. 2002;21(5):1111-7.

33. Horiguchi J, Iino Y, Takei H, Maemura M, Takeyoshi I, Yokoe T, et al. C-erbB2 status is an independent predictor of survival after first recurrence. Int J Oncol. 1998;12(1):1238.

34. Bohn U, Aguiar J, Bilbao C, Murias A, Vega V, Chirino R, et al. Prognostic Value ofthe quantitative measurement ofthe onco protein P185 (HER2/neu) in a group of patients with breast cancer and positive node involvement. Int J Cancer. 2002;101(6):539-44.

35. Nabholtz JM. HER-2 positive breast cancer. Clin Breast Cancer. 2002;3(2):75-9.

36. Fehm T, Jäger W, Krämer S, Sohn C, Solomayer E, Wallwiener D, et al. Prognostic significance of serum HER2 and CA 15-3 at the time of diagnosis of metastatic breast cancer. Anticancer Res. 2004;24(310):198792.

37. Esteva FJ, Sahin AA, Cristofanilli M, Arun B, Hortobagyi GN. Molecular prognostic factors for breast cancer metastasis and survival. Semin Radiat Oncol. 2002;12(4):319-28.

38. Andrulis IL, Bull SB, Blackstein ME, Sutherland D, Mak C, Sidlofsky S, et al. Neu/erbB2 amplif'lcation identifies a poorprognosis group pf women with nodenegative breast cancer: T oranto Breast Cancer Study Group. J Clin Oncol. 1998;16(4):1340-49.

39. Szollosi Z, Egervari K, Nemes Z, Kaczur V. Simultaneus detection of HER2/neu gene amplification and protein over expressing in paraffin embedded breast cancer. J pathol. 2005;207(1):119-20.

40. Taucher S, Rudas M, Mader RM, Gnant M, Dubsky P, Roka S, et al. Prognostic markers in breast cancer the reliably of HER-2/neu status in core needle biopsy of 325 patients with primary breast cancer. Wien klin wochenschr 2004;116(1):26-31.

41. Slamon DJ, Godolphin W, Jones LA, Holt JA, Wong SG, Keith DE, et al. Studies of HER2/neu Proto-oncogene in human breast and ovarian Cancer. Science. 1990;244(4905):707-12.

42. Pauletti G, Godolphin W, Press MF, Slamon DJ. Detection and Quantization of HER-2/neu gene amplification in human breast cancer archival material using FISH. Oncogene. 1996;13(1):63-72.

43. Pauletti G, Dandekar S, Rong H, Ramos L, Peng H, Seshadri R, et al. Assessment of methods for tissue-based detection of the HER-2/neu alternation in human breast cancer: a direct comparison of FISH and mc. J Clin Oncol. 2000;18(21):3651-64.

44. Camp RL, Dolled-Filhart M, King BL, Rimm DL. Quantitative analysis of breast cancer tissue micro arrays shows that both high and normal levels of HER2 over expression are associated with poor outcome. Cancer Res. 2003;63(7):1445-8.

45. Hirschmann A, Lamb TA, Marchal G, Padilla M, Diebold J. Simultaneous analysis of HER2 gene and protein on a single slide facilitates HER2 testing of breast and gastric carcinomas. Am J Clin Pathol. 2012;138(6):837-44

46. Hatanaka Y, Hashizume K, Kamihara Y, Itoh H, Tsuda H, Osamura RY, et al. Quantitative immunohistochemical evaluation of HER-2/ neu expression with Hercept Test in breast carcinoma by image analysis. Pathol Int. 2001;51(1):33-6.

47. Horiguchi J, Koibuchi Y, Iijima K, Yoshida T, Yoshida M, Takata D, et al. Immunohistochemical double staining with Estrogen receptor and HER2 on primary breast cancer. Int J Mol Med. 2003;12(6):855-9.

48. Mirmalek S.A, Tirgary F, Alizadeh HR. Study and comparison between malignant breast tumors and related surounding benign 
tissue about HER-2 Receptor Persistence. Iranian J surgery. 2005;13(34):48-54.[In Persian]

49. Schwartz MK, Smith C, Schwartz DC, Dnistrian A, Neiman I. Monitoring therapy by serum HER2/neu. Int J BioI Makers. 2000;15(4):324-9.

50. Streckfus C, Bigler L, Dellinger T, Dai X, Kingman A, Thigpen JT. The Presence of Soluble c-erbB2 in saliva and serum of women with breast carcinoma: a preliminary study. Clin Cancer Res. 2000;6(6):2363-70.

51. Fehm T, Gebauer G, Jäger W.. clinical utility of serial serum $\mathrm{C}$-erbB2 determinations in the follow up of breast cancer patients. Breast Cancer Res Treat. 2002;75(2):97-106.

52. Chearskul S, Sinlarat P, Bhothisuwan K, Churintrapun M, Ornrhebroi S, Klinsala N, et al. Serum c - erbB2 protein in breast cancer patients. J Med Assoc Thai. 2000;83(3):88693.

53. Meenakshi A, Kumar RS, Ganesh V, Kumar NS. Preliminary study on raidioimmunodiagnosis of experimental tumor models using technetium - 99m labeled anti - C - erbB2 monoclonal anti body. Tumori. 2002;88(6):507-12.

54. Lipton A, Ali SM, Leitzel K, Demers L, Chinchilli V, Engle L, et al. Elevated Sorum Her2/neu levels predicts decreased response to hormone therapy in metastatic Breast Cancer. J Clin Oncol. 2002;20(6):1467-72.

55. Leitzel K, Teramoto Y, Konrad K, Chinchilli VM, Volas G, Grossberg H, et al. Elevated Serum c - erbB2 antigen levels and decreased response to hormone therapy of breast cancer. J Clin Oncol. 1995;13(5):1129-35.

56. Stearns V, Yamauchi H, Hayes DF. Circulating tumor markers in breast cancer: accepted utilities and novel prospects. Breast Cancer Res Treat. 1998;52(1-3):239-59.

57. Siziopikou KP, Khan S. Correlation of HER-2 gene amplification with expression of apoptosis- suppressing gene bcl-2 and bcl-x-L in ductal carcinoma in situ of breast. APPI Appl Immunohistochem Mol Morphol. 2005;13(1):14-8.

58. Barnes DM, Millis RR. Estrogen receptors : the history, the relevance and methods of evaluation. Prog Pathol. 1995:89-94.

59. Hahrel R, Woodings T, Vivian AB. Prognostic Value of estrogen receptors in primary breast Cancer. Cancer. 1979;44(2):671-5.

60. Yamauchi H, O’Neill A, Gelman R, Carney W, Tenney DY, Hösch S, et al. Prediction of response to antiestrogen therapy in advanced breast cancer patients by pretreatment circulating levels of extra cellular domain of the HER2/neu protein. J Clin Oncol. 1997;15(7):2518-25.

61. Knowlden JM, Hutcheson IR, Jones HE, Madden T, Gee JM, Harper ME, et al. Elevated levels of epidermal growth factor receptor / C-erbB2 heterodimers mediate an autocrine growth regulatory path way in tamoxifen - resistant MCF-7 cells. Endocrinology. 2003;144(3):1032-44.

62. Witters L1, Engle L, Lipton A. Restoration of estrogen responsiveness by blocking the HER-2Ineu pathway. Oncol Rep. 2002;9(6):1163-6.

63. Allred DC, Harvey JM, Berardo M, Clark GM. Prognostic and Predictive factors in breast cancer by immunohistochemical analysis. Mod Pathol. 1998;11(2):155-68.

64. Clark GM, McGuire WL. Steroid receptors and other prognostic factors in primary breast cancer. Semin oncol. 1988;15(2 Suppl 1):205.

65. Moriki T, Takahashi T, Ueta S, Mitani M, Ichien M. Hormone receptor status and HER-2/nen over expression determined by automated immunostainer on routinely fixed cytology specimens from breast cancer. Diagn Cytopathol. 2004;30(4):251-6.

66. Balsari A, Casalini P, Bufalino R, Berrino F, Ménard S.. Role of hormonal risk factors in HER-2 positive breast cancer. Br J Cancer. 2003 88(7):1032-4.

67. Konecny G, Pauletti G, Pegram M, Untch M, Dandekar S, Aguilar Z, et al. Quantitative association between HER-2/neu and steroid hormone receptors in hormone receptor positive in primary breast cancer. J Natl Cancer Inst. 2003;95(2):142-53.

68. Davidoff AM1, Herndon JE 2nd, Glover NS, Kerns BJ, Pence JC, Iglehart JD, et al. Relation between P53 over express and established prognostic factors in breast cancer. Surgery. 1991;110(2):259-64.

69. Elledge RM, Fuqua SA, Clark GM, Pujol P, Allred DC. Williams L McGuire Memorial Symposium: the role and prognostic significance ofP53 gene alternations in breast cancer. Breast Cancer Res Treat. 1993;27(12):95-102.

70. Marks JR, Humphrey PA, Wu K, Berry D, Bandarenko N, Kerns BJ, et al. Over expression of P53 and HER-2/neu proteins as prognostic markers in early stage breast cancer. Ann Surg. 1994;219(4):332-41. 
71. Yamashita H, Nishio M, Toyama T, Sugiura $\mathrm{H}$, Zhang Z, et al. Coexistence ofHER-2 over expression and P53 protein accumulation is a strong prognostic factor in breast cancer. Breast Cancer Res. 2004;6(1):R24-30.

72. Tsutsui S, Ohno S, Murakami S, Kataoka A, Kinoshita J, Hachitanda Y. Prognostic significance of the co expression of $\mathrm{p} 53$ protein and C-erbB2 in breast cancer. Am J Surg. 2003;185(2):165-7.

73. Dep.Her CR. The new - oncogene: More than a prognostic indicator? Hum Pathol. 1994;25(12):1264-268.

74. Wilbur DC, Barrows GH. Estrogen and Progesterone receptor and G - erbB2 oncoprotein analysis in pure in situ breast carcinoma: an mc study. Mod Pathol. 1994;6(2):114-20.

75. Garne JP, Aspegren K, Linell F, Rank F, Ranstam J. Primary Prognostic Factor in invasive breast cancer with special references to ductal carcinoma and histologic malignancy grade. Cancer. 1994;73(5):143848.

76. Elston CW. Grading of invasive Carcinoma of the breast. In page DL, Andersoll Tl, editors: Diagnostic histopathology of the breast. New York; Churchill Livingstone. 1990. pp 300-311.

77. Seimi T. Histologic grades of breast cancer. Helping determine a patient s' outcome. Breast Cancer Diagnosis, 2002 Jul 10 [cited 2002 Dec 20]. Available from: [http://www. imaginis.oom].

78. Henson DE, Ries L, Freedman LS, Carriagom M. Relationship among outcome, stage of disease, and histologic grade for 22/616 cases of breast cancer. Cancer. 1991;68(10):2142-9.

79. Fisher ER, Costantino J, Fisher B, Redmond C. Pathologic findings from the National Surgical Adjuvant Breast Project. Cancer. 1992;71 (6 Suppl):2141-50.

80. Eppenberger-Castori S1, Moore DH Jr, Thor AD, Edgerton SM, Kueng W, Eppenberger $\mathrm{U}$, et al. Age - associated biomarker profiles of human breast cancer. Int J Biochem Cell Biol. 2002;34(11):1318-30.

81. Levine MN, Browman GP, Gent M, Roberts $\mathrm{R}$, Goodyear M. When is a prognostic factor useful? J Clin oncol. 1991;9(2):348-56.

82. Toikkanen S, Helin H, Isola J, Joensuu H. Prognostic significance of Her-2 oncoprotein expression in breast cancer: a 30 year follow up. J Clin Oncol. 1992;10(7):1044-8.

83. Johnson H Jr, Masood S, Belluco C, Abou-
Azama AM, Dee S, Kahn L, et al. Prognostic Factors in node - negative breast cancer. Arch Surg. 1992;127(12):1386-91.

84. Volpi A, Nanni O, De Paola F, Granato AM, Mangia A, Monti F, etal. HER - 2 expression and cell proliferation: Prognostic markers in patients with nodenegative breast cancer. J Clin Oncol. 2003;21(14):2708-12.

85. Di Giovanna MP. Clinical Significance ofHER2/neu over expression: part II, PPO update 1999; 13 (10): 1-14.

86. Tsutsui S, Ohno S, Murakami S, Kataoka A, Kinoshita J, Hachitanda Y. Prognostic value of the combination of epidermal growth factor receptor and C-erbB2 in breast cancer. Surgery. 2003; 133(2): 219-21.

87. Bast RC Jr, Ravdin P, Hayes DF, Bates S, Fritsche H Jr, Jessup JM, et al. 2000 update of recommendations for the use of tumor maker in breast and colorectal cancer: Clinical practice quid lines of the American Society of Clinical oncology. J Clin Oncol. 2001;19(6):1865-78.

88. Kronqvist P, Kuopio T, Nykänen M, Helenius H, Anttinen J, Klemi P. Predicting aggressive outcome in TINOMO breast cancer. Br J Cancer. 2004;91(2):277-81.

89. Guarneri V, Bengala C, Orlandini C, Gennari A, Donati S, Campani D, et al. Her-2 over expression as prognostic factor in metastatic breast cancer patients treated with high dose chemo therapy and autolngous stem cell support. Bone Marrow Transplant. 2004;34(5):413-7.

90. Tagliabue E, Agresti R, Carcangiu ML, Ghirelli C, Morelli D, Campiglio M, et al. Role of HER-2 in wound- induced breast Carcinoma proliferation. Lancet. 2003;362(9383):527-33.

91. Ring AE, Ellis PA. Predictors of response to systemic therapy in breast cancer. Forum (Genova). 2002;12(1):19-32.

92. Jordan Vc. Tamoxifen treatment for breast cancer: Concept to gold standard. Oncology (Williston Park). 1997 Feb;11(2 Suppl 1):713.

93. Dancey J, Sausville EA. Issues and progress with protein kinase inhibiton for cancer treatment. Nat Rev Drug Discov. 2003;2(4):296-313.

94. Stemmler HJ, Stieber P, Lässig D, Heinemann V. Re-Evaluation of HER2 status in Metastatic Breast Cancer and TumorMarker Guided Therapy with Vinorelbine and Trastuzumab. Onkologie. 2005;28(2):957. 
95. Zhang DY, Li Y, Rizvi SM, Qu C, Kearsley J, Allen BJ. Cytotixicity of breast cancer cells over expression HER2/neu by 213 BiHerceptin radio immunoconjugate. Cancer lett. 2005; 218(2):181-90.

96. Spiridon CI, Ghetie MA, Uhr J, Marches R, Li JL, Shen GL, et al. Targeting multiple Her-2 epitope with mono clonal anti bodies reliult in improved antigrowth activity of human breast cancer cell line in vitro and in vivo. Clin Cancer Res. 2002;8(6):1720-30.

97. Camirand A, Lu Y, Pollak M. Co-targeting HER2/neu and insulin -like growth factor - 1 receptors Causes synergistic inhibition of growth in HER2 - over expressing breast cancer cells. Med Sci Monit. 2002;8(12):BR521-6.

98. Harold J. HER2 over expression Breast Cancer and TranJituzumab. J Hematol Onchol. 2004;7(2).

99. Varga Z1, Caduff R, Pestalozzi B. Stability of the HER2 gene after primary chemo therapy in advanced breast cancer. Virchows Arch. 2005;446(2):136-41.

100. Ross JS, Schenkein DP, Pietrusko R, Rolfe M, Linette GP, Stec J, et al. Targeted Therapies for cancer 2004. Am J Clin Pathol. 2004;122(4):598-609.

101. Toi M, Takada M, Bando H, Toyama K, Yamashiro H, Horiguchi S, et al. Current Status of antibody therapy for breast cancer. Breast Cancer. 2004;11(1):10-4.

102. Gulhck WI. Update on HER-2 as a target for cancer therapy. Breast Cancer Res. 2001(6):390-4.

103. Bell R. What can we learn from Herceptin trials in metastatic breast cancer. Oncology. 2002;63(1):39 -46.

104. Jahanzeb M, Mortimer JE, Yunus F, Irwin DH, Speyer J, Koletsky AJ, et al. Phase II trial of weekly Vinorelbin and Trastuzumab as first line therapy in patients with HER2(+) metastatic breast cancer. Oncology. 2002;7(5):407-10.

105. Moliterni A, Ménard S, Valagussa P, Biganzoli E, Boracchi P, Balsari A, et al. HER2 over expression and doxornbicin in adjuvant chemotherapy for respectable breast cancer. J Clin Oncol. 2003;21(3):458-62.

106. Gusterson BA. Prognostic importance of c - erB2 expression in breast cancer. J Clin Oncol. 1998;10:1049-56.
107.Zhu L, Chow LW, Loo WT, Guan XY, Toi M. Her-2 Expression predicts the Response to Antiaromatase Neoadjuvant Therapy in Primary Breast Cancer. Clin Cancer Res. 2004;10(14): 4639-44.

108. Cocquyt VF, Schelfhout VR, Blondeel PN, Depypere HT, Daems KK, Serreyn RF, et al. The role of biological makers as predictors of response to preoperative Chemo therapy in large primary breast cancer. Med Oncol. 2003;20(3):221-31.

109. Christodoulou C, Klouvas G, Pateli A, Mellou S, Sgouros J, Skarlos DV. Prolonged administration of weekly paditaxel and Trastozumab in patients with advanced breast cancer. Anticancer Res. 2003;23(1):737-44.

110. Fornier MN1, Seidman AD, Schwartz MK, Ghani F, Thiel R, Norton L, et al. Serum Her2 extra cellular domain in Metastatic breast cancer patient with weekly Transtuzumab and paclitaxel. Ann Oncol. 2005;16(2):234-9.

111. Stefano R, Agostara B, Calabrò M, Campisi I, Ravazzolo B, Traina A, et al. Expression levels and Metastatic Human Breast Cancer. Ann N Y Acad Sci. 2004;1028:463-72.

112. Lear-Kaul KC1, Yoon HR, KleinschmidtDeMasters BK, McGavran L, Singh M. Her-2 status in breast cancer metastases to the central nervous system. Arch Pathol Lab Med. 2003;127(11):1451-7.

113. Carlsson J, Nordgren H, Sjöström J, Wester K, Villman K, Bengtsson NO, et al. Her-2 expression in breast cancer primary tumors and Corresponding metastases. Br J Cancer. 2004;90(12):2344-8.

114. Pietras R. New Radiation Therapy for HER2 Overexpressing Braest Cancer. Vysis 2002 [cited 2002Dec 12]; 1(1). Available from: [http://www.vysis.com].

115. Pegram MD, Salmon D. Biologic rationale for HER-2/neu as a target for mono clonal antibody therapy. Semin Oncol. 2000;27(5 Supp 9):13-19.

116. Pegram MD. Phase 11 Study of receptor - enhanced chemosensitivity using recombinant humanized anti p185 HER2 Ineu monoclonal antibody plus cisplatin patients with HER-2/neu - over expressing metastatic breast cancer refractory to chemo therapy treatment. J Clin Oncol. 1998;16(8):2659-71. 